\title{
Seroprevalence of two Important viral diseases in small ruminants in Marawi Province Northern State, Sudan
}

\author{
K. A. Enan ${ }^{1 \star}$, K. S. Intisar' ${ }^{2}$, M. A. Haj ${ }^{2}$, M. O. Hussien ${ }^{1}$, K. M. Taha ${ }^{3}$, A. M. Elfahal', \\ Y. H. Ali ${ }^{2}$ and A. M. El Hussein ${ }^{4}$ \\ ${ }^{1}$ Central laboratory, Ministry of Science and Technology, P.O. Box: 7099 Khartoum, Sudan. \\ ${ }^{2}$ Central Veterinary Research Laboratory, Virology Department P. O. Box 8067 Khartoum, Sudan. \\ ${ }^{3}$ Atbara Veterinary Research Laboratory, P. O. Box 121, Atbara, Sudan. \\ ${ }^{4}$ Animal Resources Research Corporation, Al Amarat, Khartoum, Sudan.
}

Accepted 30 December, 2011

\begin{abstract}
A survey was conducted to investigate the prevalence of Peste des petits ruminants (PPR) and sheep pox (SP) as the most economically important viral diseases of small ruminants in Marawi province at Northern state, Sudan. A total of 254 sera samples (164 ovine and 90 caprine) were collected from various localities in Marawi province during May, 2008. All collected sera were examined for PPR antibodies using competitive enzyme-linked immunoabsorbent assay (cELISA) and for SP antibodies using passive Haemagglutination test. $42(25.6 \%)$ ovine and $17(18.8 \%)$ caprine sera were positive for PPR antibodies while $51(31 \%)$ ovine and 34 (37.7\%) caprine sera were positive for sheep pox antibodies.
\end{abstract}

Keywords: PPR, Sheep pox, cELISA, PHA, Sudan.

\section{INTRODUCTION}

Peste des Petits Ruminants (PPR) disease is a severe fast spreading disease of mainly domestic small ruminants caused by PPR virus (PPRV) that belongs to Morbillivirus genus of Paramyxoviridae family. The disease is characterized by sudden onset of depression, fever, discharges from the eyes and nose, sores in the mouth, disturbed breathing and cough, foul smelling diarrhoea and death (Roeder and Obi, 1999). Goats are usually more severely affected than sheep (Roeder et al. 1994; Diallo, 2000). Economically, PPR has been considered the most important disease of sheep and goats in Sub-Saharan Africa, the Middle East, and Southwest Asia (Nussieba et al., 2009).

The first outbreak of the disease in sheep and goats in Sudan was reported in three areas in South Gedarif (Eastern Sudan) in 1971 (El Hag Ali, 1973); it was firstly diagnosed as Rinderpest (RP) and later confirmed to be PPR (El Hag Ali and Taylor, 1984). The disease was then

\footnotetext{
*Corresponding author. E-mail: khalid.enan@gmail.com.
}

reported in several outbreaks in goats in Central Sudan (Sinnar area) during 1971 to 1972 and in Mieliq (Gazira State) in 1972. PPR was then reported in sheep in Western Sudan (Rasheed, 1992); in sheep and goats in Central Sudan (Hassan et al., 1994); in sheep and goats in Khartoum State (Zeidan, 1994; El Amin and Hassan, 1998). Severe cases in which animals show clinical signs in the field can easily be detected through clinical surveillance and the detection of antigen in clinical samples, while the diagnosis of PPRV infection in subclinically infected animals can be achieved by serological surveillance (Nussieba et al., 2009).

Sheep pox is a contagious viral disease of small ruminants, which result from infection by sheep pox virus (SPV) that belongs to Capripoxvirus genus, Poxviridae family. In sheep and goats, the clinical signs vary from mild to severe. Normally, beginning with the onset of fever followed by erythematous macules that develop into papules (Spickler and Roth, 2008). Lesions may also develop on mucous membranes and on internal organs, causing systemic signs (respiratory signs, diarrhoea, depression, emaciation, abortion and sometimes death). 
Sheep pox causes considerable production losses in endemic areas as a result of reduced milk yields, decreased weight gain, abortion, poor quality wool and hides, increased susceptibility to pneumonia and flies strike, and mortality (Babiuk et al., 2008).

The first report of sheep pox in Sudan was reviewed by Bennet et al. (1944), since then many outbreaks of the disease had been reported (Muzichin and El Hag Ali, 1979; Hajer et al., 1988; Sheikh Ali, 1997). In Sudan sheep pox is considered one of the major constraints of sheep production and vaccination of sheep using sheep pox vaccine is routinely adopted for exported flocks.

In an attempt to investigate the prevalence of PPR and Sheep pox in sheep and goats in Marawi province, Northern State, Sudan; a study based on serosurveillance was conducted in several villages of Western and Eastern Nile banks in Marawi province $\left(18^{\circ} 28 \mathrm{~N}\right.$, $\left.31^{\circ} 49 \mathrm{E}\right)$. The province is situated at an altitude of 905 feet above sea level, with desert climate where maximum temperature may reach up to $42^{\circ} \mathrm{C}$ whereas, minimum temperature is $14{ }^{\circ} \mathrm{C}$, humidity is $41 \%$ and with rare rainfall. Sheep and goats in this area are raised in households for their milk, meat and as a source for cash money at times of necessity. They are usually housed in sheds made of local materials mostly tree branches and may be allowed access to grazing on grasses and residual crops in fields along River banks in some villages with larger agricultural land.

\section{MATERIAL AND METHODS}

The total population of sheep and goats in Marawi province is estimated at 20.000 and 25.000, respectively. However, not all animal owners in the area were willing to donate blood from their animals. Therefore, all animals in flocks whose owners consented to taking blood were bled for serum.

\section{Samples collection}

A total of 254 sera samples (164 ovine and 90 caprine with no prior history of vaccination to PPR or Sheep pox) were collected from 14 villages in Marawi province Western bank (Kurti, EIBasa, EIGorare, Tangasi, Marawi and Nuri) and Eastern bank (Karema, Sheba, Magashi, Hezama, EIMagal, ElKarafb, ElBarsa and Gelas). Sera were collected during May 2008.

\section{Detection of PPR antibodies using competitive ELISA (cELISA)}

Collected sera were examined for PPR antibodies using cELISA kit manufactured by CIRAD EMVT, Montpellier, France, distributed by BDSL, UK. The test is based on the competition between antibodies in sera and monoclonal antibody (MAb) to bind to the antigen. Possible binding of the MAb was detected by adding a mouse-specific conjugate and its substrate. Absence of chromogenic reaction indicated the presence of circulating antibodies whose specificity was defined by the MAb in competition. When the tested sera did not interfere with the adherence of the MAb, the wells were coloured as described by Libeau et al. (1995). The degree of coloration was read by Immunoscan (Flow laboratories, UK) reader using $492 \mathrm{~nm}$ filter. The test was performed according to the manual provided with the kits.
Detection of sheep pox antibodies using passive haemagglutination (PHA) test

PHA is more specific and sensitive test used for detecting antigens and antibodies. The application of PHA for the detection of fowl pox antibodies was reported by Tripathy et al. $(1970,1973)$ and Um Elhassan et al. (2001), and for sheep pox antibodies in Sudan (Ali et al., 2004). The overall results obtained by Ali et al. (2004) revealed higher percentage of positivity for AGID over PHA, which could be attributed to low specificity of AGID. Moreover, PHA is more likely to detect IgM antibodies than IgG which is found late in the infection (Um Elhassan et al., 2001). Preparation of serum diluents and sensitized sheep red blood cells for PHA was as described by Ali et al. (2004). The results were read for the presence of haemagglutination, the end point was taken as the highest dilution of the serum giving reading comparable to that of the positive control serum, and end points were expressed as $\log _{2}$ titers.

\section{RESULTS}

A total of 254 sera (164 ovine and 90 caprine) from different localities in Marawi province were screened for PPR and sheep pox antibodies. Out of these, 42 (25.6\%) ovine sera and $17(18.8 \%)$ caprine serum were positive for PPR antibodies. The prevalence rate of PPR antibodies in positive sheep ranged from $75 \%$ in Tangasi to $12.5 \%$ in Kurti and ElMagal, whereas, in goats it ranged from $33.3 \%$ in Karema to $12.5 \%$ in ElGorare, Tangasi, Marawi and ElMagal. The prevalence rate in Kurti, ElBasa, Sheba, Magashi, ElKarafab, ElBarsa and Gelas was 0\% (Table 1). PPR antibodies were detected in animal sera collected in all 6 villages on the west bank while only such antibodies were detected in animals in only 3 out of 8 villages on the eastern bank. The reasons for this discrepancy is not clear but might be attributed to the fact that sheep for slaughter imported to Marawi province from Northern Kordofan State first came in contact with animals of the western bank.

Regarding sheep pox, out of the 254 sera tested, 51 $(31 \%)$ ovine sera and $34(37.7 \%)$ caprine sera were positive for sheep pox antibodies. The prevalence rate of sheep pox antibodies in sheep ranged from $81.25 \%$ in EIBasa to $12.5 \%$ in kurti, Hezama, ElMagal, ElKarafab and Gelas, whereas, in goats the prevalence ranged from $100 \%$ in Magashi to $25 \%$ in Marawi and Karema. The prevalence rate in Kurti, Tangasi, ElMagal, ElKarafab, ElBarsa and Gelas was 0\% (Table 2).

\section{DISCUSSION}

Screening of sera from different localities in Marawi province for PPR antibodies showed high prevalence rate in sheep than goats $(25.6 \%$ in sheep and $18.8 \%$ in goats). Similar finding was reported by Lefèvre and Diallo (1990), Abraham et al. (2005) and Intisar et al. (2007). This increased antibodies prevalence should not be misinterpreted as an increased susceptibility of sheep to infection with PPRV. Rather, this can be attributed to a 
Table 1. The prevalence rates of PPR antibodies in sheep and goats detected using cELISA in different localities in Marawi province, Northern Sudan during 2008.

\begin{tabular}{llcccc}
\hline \multirow{2}{*}{ Bank } & Region & Tested Sheep & Goats & \multicolumn{2}{c}{ Positive PPR antibodies (\%) } \\
\cline { 5 - 5 } & Kurti & 8 & 8 & $1(12.5 \%)$ & Goat \\
\hline \multirow{6}{*}{ Western } & ElBasa & 16 & 6 & $4(25 \%)$ & $0 \%$ \\
& ElGorare & 16 & 6 & $8(50 \%)$ & $0 \%$ \\
& Tangasi & 16 & 6 & $12(75)$ & $1(6.25 \%)$ \\
& Marawi & 15 & 8 & $11(73.3 \%)$ & $1(6.25 \%)$ \\
& Nuri & 15 & 8 & $5(33.3 \%)$ & $1(6.6 \%)$ \\
& Karema & & & & $4(26.6 \%)$ \\
& Sheba & 15 & 8 & $0 \%$ & $5(33.3 \%)$ \\
& Magashi & 15 & 8 & $0 \%$ & $0 \%$ \\
\multirow{5}{*}{ Eastern } & 8 & 6 & $0 \%$ & $0 \%$ \\
& Hezama & 8 & 6 & $0 \%$ & $4(50 \%)$ \\
& ElMagal & 8 & 6 & $1(12.5)$ & $1(12.5 \%)$ \\
& Elkarafab & 8 & 8 & $0 \%$ & $0 \%$ \\
Total & ElBarsa & 8 & 8 & $0 \%$ & $0 \%$ \\
& Gelas & 8 & 8 & $0 \%$ & $0 \%$ \\
& & 164 & 90 & $42(25.6 \%)$ & $17(18.8 \%)$ \\
\hline
\end{tabular}

Table 2. Seroprevalences of Sheep pox in sheep and goats detected using PHA in different localities in Marawi province, Northern Sudan during 2008.

\begin{tabular}{|c|c|c|c|c|c|}
\hline \multirow{2}{*}{ Bank } & \multirow{2}{*}{ Region } & \multirow{2}{*}{ Tested sheep } & \multirow{2}{*}{ Goats } & \multicolumn{2}{|c|}{ Positive samples } \\
\hline & & & & Sheep & Goats \\
\hline \multirow{6}{*}{ Western } & Kurti & 8 & 8 & $1(12.5 \%)$ & $0 \%$ \\
\hline & ElBasa & 16 & 6 & $13(81.25 \%)$ & $5(83.3 \%)$ \\
\hline & EIGorare & 16 & 6 & $5(31.25 \%)$ & $2(33.3 \%)$ \\
\hline & Tangasi & 16 & 6 & $4(25 \%)$ & $0 \%$ \\
\hline & Marawi & 15 & 8 & $6(40 \%)$ & $2(25 \%)$ \\
\hline & Nuri & 15 & 8 & $10(66.6 \%)$ & $3(37.5 \%)$ \\
\hline \multirow{8}{*}{ Eastern } & Karema & 15 & 8 & $0 \%$ & $2(25 \%)$ \\
\hline & Sheba & 15 & 8 & $4(26.6 \%)$ & $4(50 \%)$ \\
\hline & Magashi & 8 & 6 & $2(25 \%)$ & $6(100 \%)$ \\
\hline & Hezama & 8 & 6 & $1(12.5 \%)$ & $3(50 \%)$ \\
\hline & EIMagal & 8 & 6 & $1(12.5 \%)$ & $0 \%$ \\
\hline & Elkarafab & 8 & 8 & $1(12.5 \%)$ & $0 \%$ \\
\hline & ElBarsa & 8 & 8 & $2(25 \%)$ & $0 \%$ \\
\hline & Gelas & 8 & 8 & $1(12.5 \%)$ & $0 \%$ \\
\hline Total & & 164 & 90 & $51(31 \%)$ & $34(37.7 \%)$ \\
\hline
\end{tabular}

higher recovery rate (lower case fatality rate) and / or a greater longevity of sheep versus goats.

PPR is existing in Sudan since its first reported Outbreak in 1971 (El Hag, 1973). However, northern States were known to be free of PPR until the detection of it's antibodies in sheep (53.3\%) and goat (41.7\%) sera collected from the Northern Sudan using cELISA (Intisar et al., 2010). The overall detected seroprevalence of PPR in Marawi province was $23.2 \%$, although it is lower than that recently reported in the Northern Sudan (51.4\%) (Intisar et al., 2010), it points to the wide spread of PPR in the Northern State. This is probably due to cessation of 
Rinderpest (RP) vaccination campaigns in the country during which sheep and goats were vaccinated with RP vaccine. Similar increase in incidence of PPR outbreaks was reported from India after cessation of RP vaccination (FAO, 1999).

Sheep pox was reported in different localities in Sudan (Ali et al., 2004) Serosurveillance from various parts in Marawi province for sheep pox antibodies using passive haemagglutination (PHA) test revealed seropositivity in 31 and $37 \%$ in sheep and goats, respectively.

The highest prevalence rates of sheep pox seropositivity were observed in ElBasa $(81.25 \%)$ and Nuri $(66.6 \%)$ villages and this may be due to close contact of several flocks for grazing and watering, leading to better opportunities for disease transmission. Such a picture was also observed by Ali et al. (2004) in River Nile State. Although this area is considered poor in animal resources with sparse animal population, however household raising of small ruminants plays an important role in the village economy and food security, as these animals practice provide for meat, milk and act as a source of ready cash. The area is also part of the disease free zone where animals from other parts can be conditioned for export. The building of the new Marawi dam with expected increase in agricultural and animal production activities adds to the importance of Northern State not only as transit place for export animals but also as an area where animals can be reared and raised for local consumption and export. It is thus important to study endemic diseases in the area to help undertake appropriate control measures.

\section{REFERENCES}

Abraham G, Sintayehu A, Libeau G, Albina E, Roger F, Laekemariam Y, Abayneh D, Awoke KM (2005). Antibody sero-prevalences against peste des petits ruminants (PPR) virus in camels, cattle, goats and sheep in Ethiopia. Prev. Vet. Med. 70(1-2):51-57.

Ali YH, Wegdan HA, Amira ME, Intisar KS (2004). Detection of sheep pox antibodies in different areas in Sudan using agar gel immunodiffusion (AGID) and passive haemagglutination test (PHA). Sud. J. Vet. Sci. Anim. Husb. 43(1,2):123-131.

Babiuk S, Bowden TR, Boyle DB, Wallance DB, Kitching RP (2008). Capripoxviruses: an emerging worldwide threat to sheep, goats and cattle. Transbound. Emerg. Dis. 55:263-272.

Bennet SC, Horgan ES, Hasseb MA (1944). The pox disease of sheep and goats. J. Comp. Path. 54:131-160.

Diallo A (2000). Peste des petits ruminants. In: OIE Manual of Standards for Diagnostic Tests and Vaccines, $4^{\text {th }}$ edition. Chapter 2.1.5. Office international des Epizooties, Paris. pp. 114-122.

El Amin MA, Hassan AM (1998). The seromonitoring of Rinderpest throughout Africa, phase III results for 1998. IAEA, VINNA, Food and Agriculture Organization (FAO) / International Atomic Energy Agency (IAEA).
El Hag Ali B (1973). A natural outbreak of Rinderpest involving sheep, goats and cattle in Sudan. Bull. Epizoot. Dis. Afr. 12:421-428.

El Hag Ali B, Taylor WP (1984). The isolation of PPR from the Sudan. Res. Vet. Sci. 36:1-4.

FAO (1999). New technologies in the fight against transboundary animal diseases. FAO animal production FAO- Rome 1999. pp. 103144

Hajer I, Abass B, Abu-Samra MT (1988). Capripox virus in sheep and goats in the Sudan. Revue d Elevage et de Medecine Veterinaire des Pays Tropicaux. 41(2):125-128.

Hassan AK, Ali YO, Hajir BS, Fayza AO, Hadia JA (1994). Observation on epidemiology of peste des petits ruminant in Sudan. Sud. J. Vet. Res.13:29-34.

Intisar KS, Ali YH, Khalafalla Al, Mahasin EA/Rahman (2010). Current situation of Peste des petits ruminants (PPR) in the Sudan. Trop. Anim. Health Prod. 42(1):89-93.

Intisar KS, Khalafalla AI, El Hassan SM, El Amin MA (2007). Detection of peste des petits ruminants (PPR) antibodies in goats and sheep in different areas of Sudan using competitive ELISA. Proceedings of the 12th International Conference of the Association of Institutions for Tropical Veterinary Medicine.P 427. Montpellier, France 20-22 August 2007.

Lefèvre PC, Diallo A (1990). Peste des petits ruminants virus. Review scientific technology Office International Epizootics 94:951-965.

Libeau G, Perhaud C, Lancelot R, Colas F, Gurre L, Bishop DH, Diallo A (1995). Development of competitive ELISA for detecting antibodies to the peste des petits ruminants virus using a recombinant nucleoprotein. Res. Vet. Sci. 58:50-55.

Muzichin SI, El Hag AB (1979). A study of sheep pox in the Sudan. Bull. Anim. Health Prod. Afr. 27:105-112.

Nussieba AO, Ali AS, Mahasin EA/ Rahman, Fadol MA (2009). Antibody seroprevalences against Peste des Petits Ruminants (PPR) virus in sheep and goats in Sud. Trop. Anim Health Prod. 41:1449-1453.

Rasheed IE (1992). Isolation of PPRV from Darfur State. (Unpublished MSc Thesis, University of Khartoum, Sudan).

Roeder PL, Abraham G, Kenfe G, Barrett T (1994). Peste des petits ruminants in Ethiopian Goats. Trop. Anim. Health Prod. 26: 69-73.

Roeder P, Obi TU (1999). Recognizing of peste des petits ruminants. In: FAO Animal Health Manual (5). Publ. Food and Agriculture Organization of the United Nations, Rome, Italy.

Sheikh Ali MA (1997). Studies on sheep pox, goat pox and contagious ecthyma viruses in the Sudan. (Unpublished MVSc thesis, University of Khartoum-Sudan).

Spickler AR, Roth JA (2008). In Emerging and Exotic Diseases of Animals. $3^{\text {rd }}$ edition. Ames: lowa State University, Ames-Aowa-USA.

Tripathy DN, Hanson LE, Killinger AH (1973). Studies on differentiation of avian pox viruses. Avian Dis.17:325-333.

Tripathy DN, Hanson LE, Myers WL (1970). Passive haemagglutination test with fowl pox virus. Avian Dis. 14:29-38.

Um Elhassan WA, El Hussein AM, Abdel Gadir B, Tamador MA (2001). Detection of fowl pox antibodies in chickens using three serological methods. Sudan. J. Vet. Sci. Anim. Husb. 40:(1,2):127-131.

Zeidan M (1994). Diagnosis and distribution of PPR in small ruminants in Khartoum State during 1992-1994. (Unpublished MSc Thesis, University of Khartoum, Sudan). 